\title{
THE LAST HUNTER-GATHERER COMMUNITIES FROM MIDDLE NAREW RIVER VALLEY - ENVIRONMENTAL CONTEXT. CASE STUDY FROM GRĄDY-WONIECKO SITE (NE POLAND - WIZNA BASIN)
}

DOI: http://dx.doi.org/10.18509/GBP.2018.20

UDC: 911.372.3:316.324.22]:908(438)

\author{
Tomasz Kalicki ${ }^{1}$ \\ Marcin Frączek ${ }^{1}$ \\ Adam Wawrusiewicz ${ }^{2}$ \\ ${ }^{1}$ Jan Kochanowski University in Kielce, Institute of Geography, Kielce, Poland, \\ tomaszkalicki@ymail.com; marcinfraczek1987@gmail.com, \\ ${ }^{2}$ Podlachian Museum in Białystok, Poland, adamwawrusiewicz@op.pl
}

\begin{abstract}
Study area is located in NE Poland in the Wizna Basin, the most southern part of Biebrza Basin, which is in origin erosion or melt-out depression with wide bottom. Relief of this region formed during Middle Polish (Saalian) - Warta stage) and Vistulian Glaciations. The Grądy-Woniecko archaeological site is situated on elevation (erosion remnant) on the border of fluvial and non-fluvial segments of the basin near Narew River. The research of archeological site (on site study) and surroundings (off site study) was done. Two generations of Late Glacial large meanders of Narew river were discovered and some phases of aeolian processes activity climatically (Older and Younger Dryas) and anthropogenically (Subboreal - 4000-1600 BC; Subatlantic - 1200-1600 AD and after 1800 AD) conditioned. Dune complex at Grądy-Woniecko was undercut by Narew river during the Atlantic-Subboreal. It was a place of outstanding significance at the end of Stone Age for the people of Neman culture circle. The settlement activity in this area probably involved regular re-occupations by the same societies. The sandy island near the confluence of the Narew and Biebrza Rivers might have meant something more to the last hunter-gatherers, which is implied by the remains associated with indications of ritual practices, such as burials, dispersed remains of cremated bones, deposits of flint artefacts, or residues of psychoactive substances identified on the walls of pottery vessels.
\end{abstract}

Keywords: hunter-gatherer communities, geoarchaeological research, Wizna Basin,

\section{INTRODUCTION}

Grądy-Woniecko archaeological site 1 (approx. 4.5 ha) is located in NE Poland (Podlachian Voivodeship) in the Wizna Basin on distinct relief elevation on the border of fluvial and non-fluvial segments of the basin (Fig. 1). The site located about $7 \mathrm{~km}$ downstream of Narew and Biebrza rivers confluence and approx. $100 \mathrm{~m}$ from the modern Narew riverbed. The site was discovered and first excavated in 1974 and also in next years [ 1 therein references]. Present-day research of archeological site (on site study) and surroundings (off site study) was done. Main topics were verification stratigraphy of the site and palaeogeographical reconstruction of environmental context for time span of the Subneolithic culture circle. 


\section{LOCATION}

Biebrza Basin is a distinct and important macro-depression with complex structure in relief of NE Poland (Fig. 1). The evolution of this form included several stages of relief transformation during the last two Pleistocene glaciations and two interglacial periods Eemian and Holocene [3]. The origin and age of Biebrza Basin was associated with erosion processes of proglacial waters (e.g [4], [5]) or dead ice-melting (e.g. [6], [7]) connected with Oder and Wartha (Saalian) ice sheet [7] or Vistulian - Świecie stadial before LGM. Biebrza Basin includes 5 basins and most southern of them, Wizna Basin (length $23 \mathrm{~km}$, width $11 \mathrm{~km}$ ), was studied (Fig. 1). Many forms related with ice-melting (e.g moraine monadnocks, sandur plain, keme terraces and kemes) and composed with highly textural and structural diverse fluvioglacial and glacial deposits occur within it. Those monadnocks (erosion remnants) rise above the peat-bog plain in the basin bottom.

\section{PALAEOGEOGRAPHICAL RESULTS OFF SITE STUDY}

Two segments can be distinguished in the bottom of the Wizna basin: one which is wide ( $2 / 3$ of the bottom width) devoid of traces of fluvial activity, and the other - narrower, fluvial (Fig. 1).

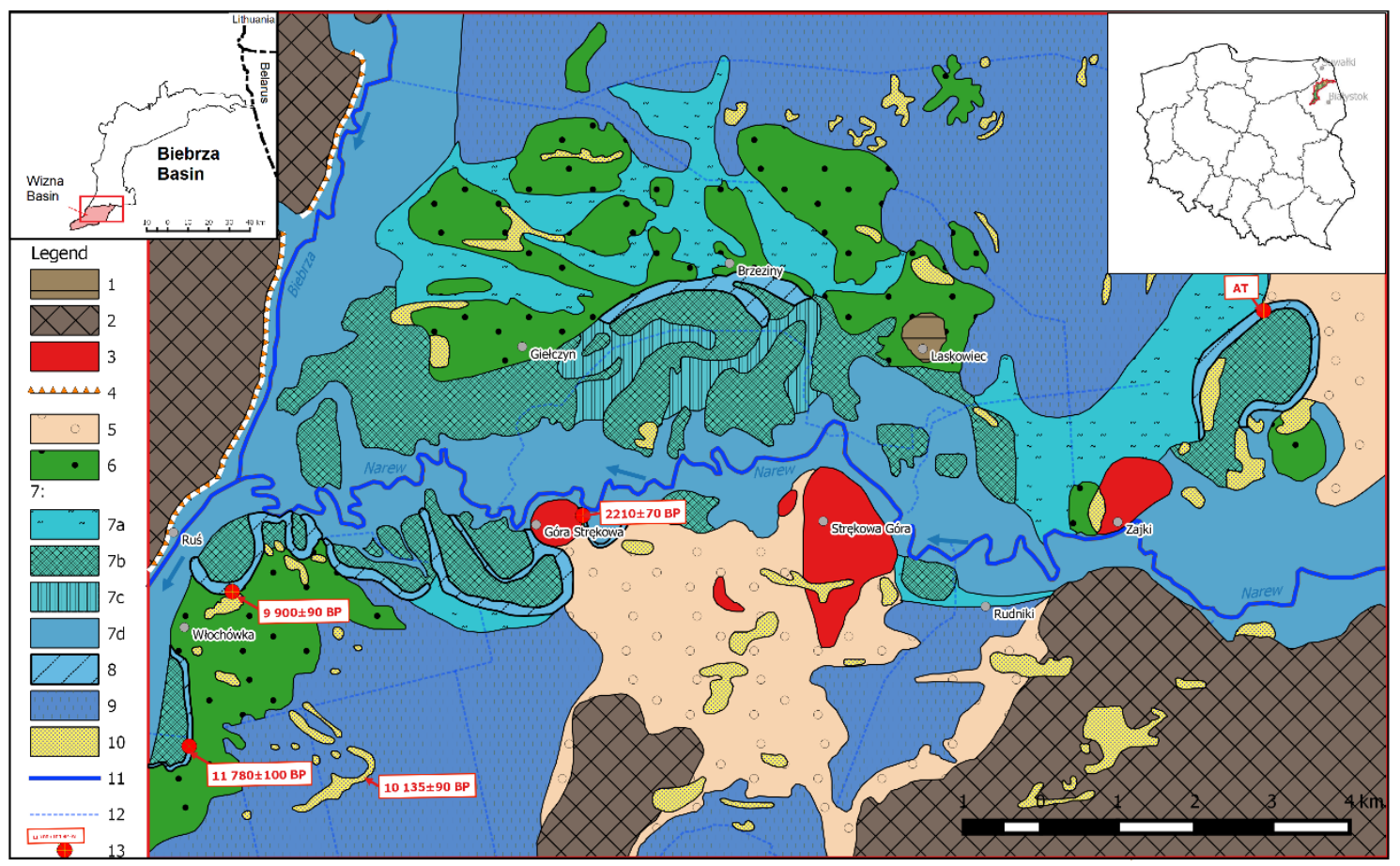

Figure 1. Location of study area and geomorphological map of the Narew and Biebrza rivers confluence in Lower Biebrza-Wizna Basins (by Banaszuk changed and completed in [1])

1 - moraine islands on the accumulation plains in Biebrza Basin floor, 2 - moraine upland/ground moraine, 3 -denudational remnants/kemes, 4 - edges, 5 - sandy plains from old Vistulian ice sheet deglaciation, 6 - terrace, 7 - floodplain steps: 7a - I; from Pleistocene/Holocene limit, 7b - II; Late Glacial (Early Holocene?), 7c - III; Late Atlantic, 7d - IV; Subatlantic (present-day), 8 - large palaeomeanders, 9 - peat bogs, 10 - dunes, field of aeolian sands, 11 - watercourses, 12 - drainage ditches, 13 -

$$
{ }^{14} \mathrm{C} / \text { paleobotanical dates }
$$


In the first segment the relief of biogenic deposits bottom indicate the occurrence of palaeolake filled with gyttja deposits. Origin of these depressions was degradation of permafrost and aeolian processes. At Wizna I profile the upper part (depth 5.42-5.35 m) of lake deposits (detritus-clayey gyttja) and sedge-moss peats in superposition (depth 5.35-5.25 m) were dated at $12710 \pm 240$ and $12610 \pm 190$ BP respectively. This type represent also present-day existing Maliszewskie Lake with gyttja $22.5 \mathrm{~m}$ thick. The thin layer of moss peats (depth 4.81-4.73 m) accumulated on permafrost in coastal zone of this present-day lake was dated at $11460 \pm 210 \mathrm{BP}$ [8]. Grzędy site is located within the non-fluvial segment and includes dune complex surrounded by peats whose thickness

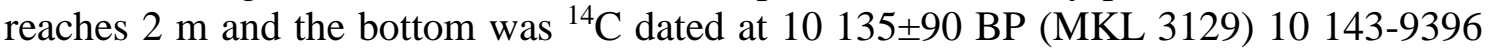
cal. BC. The surface under the peats was transformed by aeolian processes at the end of last glaciation and the Younger Dryas cooling resulted, in probably, that the complex of parabolic dunes was still active at the end of the Late Glacial and Early Holocene. After the climate warming in the Preboreal starts the accumulation of peats but with short-time an increase of aeolian processes activity in the beginning of the Atlantic - 8320 $\pm 80 \mathrm{BP}$ (MKL 3274) 7542-7141 cal. BC. It could be coincided with global cooling and more open vegetation on sand dunes. It is also not excluded impact of the Mesolithic cultures (single flint artefact was found in dune sands).

Within the fluvial segment can be distinguished sandy terrace and muddy-boggy, with numerous oxbow lakes, floodplain of Narew river, which have four levels of different age [1 therein references]. At the edge of the terraces there are preserved macromeanders whose cut off was ${ }^{14} \mathrm{C}$ dated at $11780 \pm 100 \mathrm{BP}$ (MKL 3130) $11851-11461 \mathrm{cal}$. BC (Włochówka site) and at 9900 \pm 90 BP (MKL 3135) 9762-9231 cal. BC (Ruś site). Palaeomeander, which undercuts from the north sand dune with archaeological site Grądy-Woniecko, was cut off before 3800 060 BP (MKL 3127) 2461-2043 cal. BC. High facial diversity of deposits filled this palaeomeander indicates distinct changes in sedimentation conditions in the Neoholocene, probably referring mainly to climate changes (frequency and magnitude of floods), and it is not connected with changes in location of Narew riverbed, because the river in this period flowed probably stable along edge of Kolno Upland.

\section{PALAEOGEOGRAPHICAL RESULTS ON SITE STUDY}

Grądy-Woniecko dune complex, together with the archaeological site situated within its area, is located in the fluvial segment of the Wizna Basin. It most probably emerged at the end of the Younger Pleniglacial, when the aeolian processes shaped the places where pro-glacial waters ceased their activity. However, the present form of the elevation results from more recent transformations and remodelling of the surface. Within aeolian sediments could be distinguished several members separated by buried soils. Stratigraphy, number, depth and age of buried soils is strongly various in different parts of the dune complex, because at different periods they were activated only some parts of the dune field (Fig. 2).

It is likely that the rate of lateral migration of the Narew river increased in the Late Boreal and Early Atlantic, which was a phase of intensification of fluvial activity, known from many valleys (cf. [9]). As a consequence, extensive areas of sandy point bars (dated to approx. 8.6 $\pm 1.3 \mathrm{ka}$; UJK-OSL-71) were formed and they can be found under the central portion of the present-day dune field, separated from the aeolian sands with buried soil. Corresponding chronology is associated with the dislocation of the parabolic dune at 
Grzędy, nevertheless, the origin of this process (climatic/anthropogenic?) cannot be established at this stage of research.

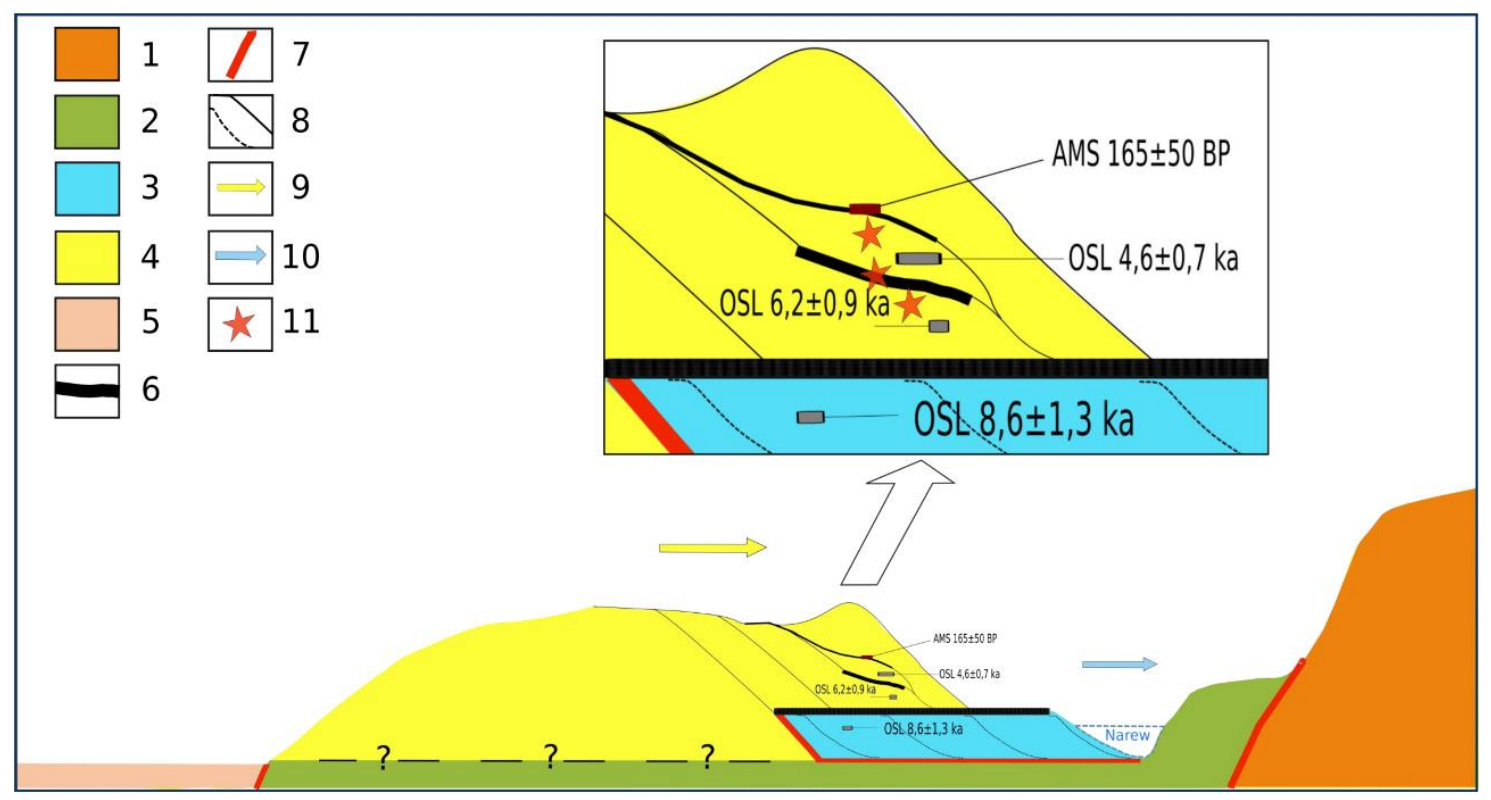

Figure 2. Stratigraphic scheme of the archaeological site at Grądy-Woniecko [1] 1 - moraine upland, 2 - fluvioglacial sediments and the Pleistocene alluvia, 3 - the Holocene alluvia, 4 aeolian deposits, 5 - biogenic deposits, 6 - buried soils, 7 - erosional limits, 8 - accumulation limits, 9 direction of aeolian transport, 10 - direction of lateral channel migration, 11 - layers with artefacts

At least a part of the dune surface was still active or resumed the activity in the NE portion during the Atlantic climatic optimum. It was a period of deposition of subsequent aeolian layers that covered fluvial sands as well as formation of this portion of the dune field. The chronology of this sands, located below the level which comprised the artefacts, was established by OSL method at $6.2 \pm 0.9 \mathrm{ka}$ (UJK-OSL-66). At that time, the river probably flowed directly next to the northern side of the dune and undercut the whole complex. Exposure of aeolian sands on the erosional bank of the meander of the Narew river might have constituted one of the natural causes why this part of the dune was activated. This aeolian member ends with well-developed buried soil with artefacts. This soil was fossilized in the early Subboreal, because aeolian sands covering it were OSL dated at $4,6 \pm 0,7 \mathrm{ka}$ (UJK-OSL-65). These two phases of aeolian activity may be related with human activity of the Niemen culture on the area of dune field. This is confirmed by radiocarbon AMS dates of human bones (5325 \pm 35 and $5100 \pm 35 \mathrm{BP})$ and charred organic remain in pottery $(5035 \pm 35$ and $4560 \pm 50 \mathrm{BP})$.

The next phase of aeolian activity may already be connected with the Middle Ages and the Modern period. The first phase/phases? from this period can be dated to the early Middle Ages - aeolian sands were OSL dated at 1,2 $\pm 0,18 \mathrm{ka}$ (UJK-OSL-63) and 0,9 $\pm 0,13$ ka (UJK-OSL-67), and another refers with the Middle Ages (OSL date 0,54 $\pm 0,08 \mathrm{ka}-$ UJK-OSL-64). Period of the Medieval aeolian activity closes fossil soil dated AMS at

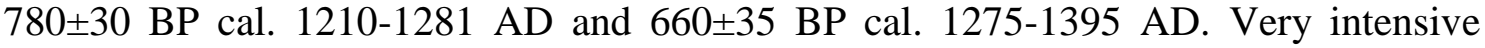
aeolian activity in the Modern period led to the destruction of local elders both aeolian series and buried soils, that is why the fossil soil radiocarbon dated at $165 \pm 50 \mathrm{BP}$ (MKL 3128 ), which is the last 3 centuries (after 1657 AD) or AMS dated at 190 $\pm 30 \mathrm{BP}$ after cal. 1664 AD locally occurs on the Subboreal sands at depth. $150 \mathrm{~cm}$, and elsewhere on the surface. Very intensive changes in the morphology of the area connected with the 
activities of aeolian processes in recent decades documents the comparison of the relief of the dune present day and from 1974 when were conducted archaeological excavations.

\section{ARCHAEOLOGICAL RESULTS ON SITE STUDY}

The materials recovered in 1974 provide the basic component for this study. It is definitely the richest and most numerous part of the assemblage of eco- and artefacts discovered in situ. The pattern of layers recorded at that time was confirmed by presentday boreholes.

The most distinctive part of the collection is constituted by pottery vessels. It consists of 7648 fragments, 7311 of which could be associated with settlement activity of Subneolithic societies, identified with different phases of development and regional groups of the Neman cultural circle. The other ones are connected with the Early Iron Age (252 fragments) and Late Modern Period (81 fragments). Six stylistic groups of ceramic were distinguished and they comprised components of the decoration (decoration groups), morphology (macro- and micromorphology), technology (technological groups). As a result of the completed work, it can be concluded, that the beginning of Subneolithic settlement activity at the site took place as early as the mid-5th millennium BC, which is implied by the fragments of vessels associated with the first stylistic group (correspond with the early Subneolithic Sokołówek type, which was synchronic with the pottery of Pripyat-Neman culture in the East-European unit). The classic Neman culture most probably emerged in the late 5th and early 4th millennium BC. It is confirmed by ${ }^{14} \mathrm{C}$ date for organic residues found in a vessel from the 2nd stylistic group. Final period of Subneolithic settlement can be connected with second half of the 3rd millennium BC when new cultural groups emerged in Mazovia and Masurian Lake District $\left(6^{\text {th }}\right.$ stylistic group).

The flint assemblage, comprising 10620 items, could be divided into two groups: unearthed in the course of exploration of the trenches, where they were associated with pottery (approx. 1/3 of the assemblage) and the ones collected from the soil surface on the dislocated portions of the dune (approx. 2/3 of the assemblage). The flint artefacts was almost exclusively made of local chalk erratic raw material. Raw materials of foreign provenance are represented by four specimens made of chocolate flint and one made of Volhynian flint. Three genetic facies were distinguished in the analysed assemblage: debitage products (cores, blades, flakes, chips), products of debitage modification (tools and associated waste material) and damaged items, i.e. uncharacteristic fragments (bits, chunks) of cryo- or thermogenic origin. The flint inventory can be divided into two separate, although sometimes overlapping techno-typological components. They seem to reflect two different cultural traditions sensu largo, i.e. Mesolithic and Neolithic. Additionally, the former includes three lines: "Komornica", "Janisławice" and "ChojnicePieńki".

Apart from portable sources, outlines of in-ground features were discovered, although it is possible that they were not connected with the activity of Prehistoric people. In addition, distinct outlines of two pits with human bone remains and sparse animal bones were found in the northern part of the site. Owing to the context of these finds, they were identified as funerary features (human skulls and burned bones). Fragments of a skull of an adult individual of relatively advanced age, probably male, were discovered at the bottom of grave No. 1 . The ${ }^{14} \mathrm{C}$ date for the skull falls within the range of 4235-4066 BC, which would correspond with the earliest horizon of the Subneolithic sequence of the 
occupation of the dune. Another interesting group of features were two deposits of flint artefacts.

Apart from the main settlement sequence, which transpired at the end of the Stone Age and was still in progress at the beginning of the Bronze Age, materials which indicated penetration of this dune complex in more recent periods were also identified. One of them consists of a few fragments of vessels connected with the Trzciniec cultural circle. However, they were discovered at the edge of another dune field and they are not directly related to site 1 . The surface of the latter also delivered remains of settlement activity from the Iron Age and fragments of vessels associated with the village of Wonieck which functioned in this area in the late $19^{\text {th }}$ and early $20^{\text {th }}$ century.

\section{DISCUSSION}

The limited series of radiocarbon dates is insufficient for reconstruction of the complete image of the chronology of the hunter-gatherer societies that populated this place in the Neolithic and Early Bronze Age. The oldest dates oscillate around the late $5^{\text {th }} /$ early $4^{\text {th }}$ millennium BC, when the dune was the venue for funerary practices, whose traces were preserved as graves and cremated bones. Comparable results were achieved in the case of radiocarbon dating of organic residues found on the surface of a vessel from the early phase of the Neman culture. It must be stressed that the analysis of ceramic sources shifted the beginning of the "settlement activity" to the first half of the $5^{\text {th }}$ millennium BC. The end of the sub-Neolithic settlement sequence probably took place in the late $3^{\text {rd }} /$ early $2^{\text {nd }}$ millennium BC, which is expressed in the pottery of the late Linin-proto-Trzciniec type. The presence of Subneolithic pottery together with Mesolithic flint artefacts is another issue. The stratigraphic data and results of absolute dating by means of the OSL method provide enough information to place the sequence of the deposits which accommodate the sources in the time span between the mid-Atlantic $(6.2 \pm 0.9 \mathrm{ka})$ and the modern era. In the cultural context of discussion, the first date indicates the terminus ante quem for the oldest remains of human presence. Thus it delivers unquestionable evidence for the co-occurrence of Subneolithic pottery with Mesolithic flint materials.

\section{CONCLUSIONS}

Two generations of large, Late Glacial meanders: older probably from Bölling (Włochówka site) and younger, probably from Alleröd (Ruś site) belong to macromeander pattern functioned in many lowland river valleys of Central Europe during the late Pleistocene (comp. [9]). Also less meandering pattern of the older generation shows, that they was transitional system from braided to meandering river, similar like in Warta and Moza valleys [10].

It could be believed that the spacious and characteristic dune complex in GradyWoniecko was a place of outstanding significance at the end of the Stone Age. It probably resulted from its topography - a big dry island located among bogs and marshes of a big river, whose main course was adjacent to the dune - this is a perfect landscape for "exploitation" by the hunter-gatherers of that time. The importance of the area was also a consequence of its location along the communication routes coinciding with the lines of latitude, which combined, by means of the Narew, Supraśl and Neman Rivers catchment areas, two different cultural zones - Neolithic and Mesolithic ones. Thus it is no surprise that the dune was repeatedly occupied by different human societies. In the Neolithic, the 
settlement activity in this area probably involved regular re-occupations by the same societies from the Neman cultural circle. The sandy island near the confluence of the Narew and Biebrza Rivers might have meant something more to the last hunter-gatherers, which is implied by the remains associated with indications of ritual practices, such as burials, dispersed remains of cremated bones, deposits of flint artefacts, or residues of psychoactive substances identified on the walls of pottery vessels (Fig. 3).
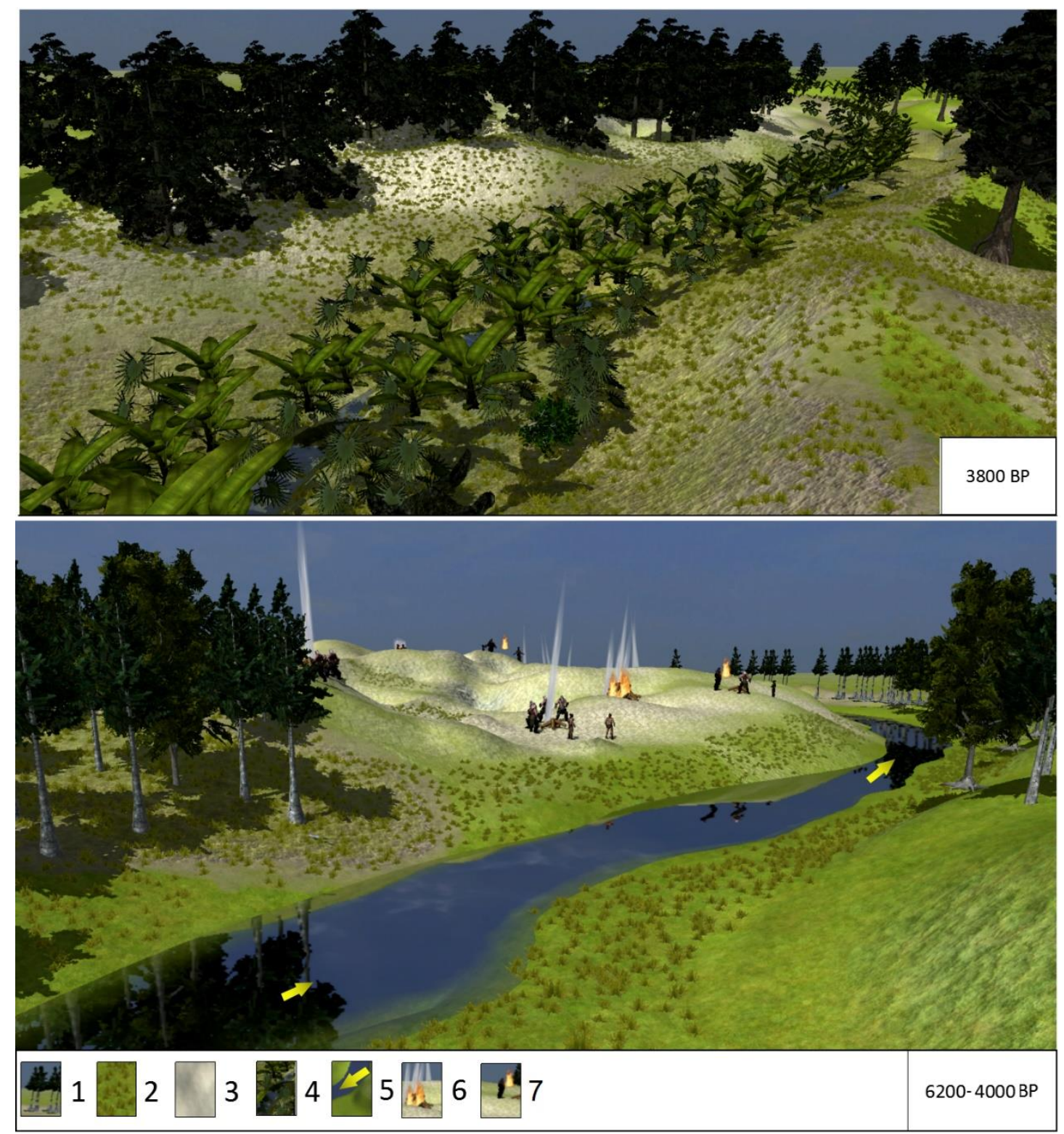

Figure 3. Schematic 3D model of Grądy-Woniecko site (northern part): 6200-4000 BP and 3800 BP [1] 1 - forest, 2 - grassland, 3 - sandy elevations/dunes, 4 - abandoned channel of Narew river (oxbow lake), 5

- Narew riverbed, 6 - burial customs (cremation - partial/complete), 7 - hunter-gatherer communities of Niemen culture

Separate phases of aeolian activity at the Grądy-Woniecko archaeological site have a high conformity with the general phases dune formation for Poland [11], and phases of activity and stabilization of the nearby dune field in Narew and Biebrza watershed (Kiślaki site)[12]. The second author distinguished phases of an increased aeolian activity 
climatically (Older and Younger Dryas) and anthropogenically (Subboreal - 4000-1600 BC; Subatlantic - 1200-1600 AD and after 1800 AD) conditioned.

\section{AKNOWLEDGMENTS}

Research was founded by project of Polish Ministry of Culture and National Heritage No. 3222/16/FPK/NID "Pomiędzy Wschodem a Zachodem. Osadnictwo z epoki kamienia i prologu epoki brązu w Grądach-Woniecko, woj. podlaskie".

\section{REFERENCES}

[1] Wawrusiewicz A., Kalicki T., Przeździecki M., Frączek M., Manasterski D. Grądy-Woniecko. Ostatni łowcy-zbieracze znad środkowej Narwi, Muzeum Podlaskie w Białymstoku, Białystok, 2017.

[2] Frączek M. Warunki przyrodnicze funkcjonowania społeczeństw subneolitycznych w Kotlinie Biebrzy, (typescript of $\mathrm{PhD}$ thesis), Biblioteka Uniwersytecka Uniwersytetu Jana Kochanowskiego w Kielcach, Kielce, 2017.

[3] Grabińska B., Kubeł S. Geneza doliny Narwi i terenów bezpośrednio przyległych w badaniach geologiczno-geomorfologicznych Polski NE. Zesz. Nauk., Ostrołęckie Towarzystwo Naukowe im. A. Chętnika, Ostrołęka, XXV., 53-61, 2011.

[4] Galon R., Roszko L. Zasięgi lądolodów skandynawskich i ich stadiów recesyjnych na obszarze Polski, (in:) Czwartorzęd Polski, PWN, Warszawa, 1967.

[5] Żurek S. Geomorphology of the Biebrza valley [in:] Towards protection and sustainable use of the Biebrza Wetlands: Exchange and integration of research results for the benefit of a PolishDutch Joint Research Plan, (eds. H. Okruszko, M. J. Wassen). Utrecht, 15-47, 1994.

[6] Banaszuk H. (ed.), Kotlina Biebrzańska i Biebrzański Park Narodowy. Aktualny stan, walory, zagrożenia i potrzeby czynnej ochrony środowiska. Monografia przyrodnicza. Wyd. Ekonomia i Środowisko, Białystok, 2004.

[7] Musiał A. Studium rzeźby glacjalnej północnego Podlasia, Rozprawy Uniwersytetu Warszawskiego 403, 1992.

[8] Balwierz Z., Żurek S. The Late-Glacial and Holocene vegetational history and paleohydrological changes at the Wizna site (Podlasie Lowland), Acta Palaeobotanica, 27/1, 121136, 1987.

[9] Kalicki T. Zapis zmian klimatu oraz działalności człowieka i ich rola w holoceńskiej ewolucji dolin środkowoeuropejskich, Prace Geograficzne IGiPZ PAN 204, 348 p, 2006.

[10] Vandenberghe J., Kasse C., Bohncke S., Kozarski S. Climate-related river activity at the Weichsetian-Holocene transition: a comparative study of the Warta and Maas rivers, Terra Nova, 6, 476-485, 1994.

[11] Nowaczyk B. Wiek wydm, ich cechy granulometryczne i strukturalne a schemat cyrkulacji atmosferycznej w Polsce w późnym vistulianie i holocenie, Poznań, 1986.

[12] Grzybowski J. Rozwój wydm w południowo-wschodniej części Kotliny Biebrzańskiej, Wrocław-Warszawa-Kraków-Gdańsk-Łódź, 1981. 